\title{
Effects of intensive agriculture and hydrological changes on macrophyte and macroinvertebrate assemblages in lowland riverine wetlands
}

Paula Altieri ( $\square$ altieripaula@gmail.com )

Insituto de Limnología Dr. Raúl A. Ringuelet https://orcid.org/0000-0001-6858-8099

\section{Carolina Ocon}

Instituto de Limnologia Dr Raul a Ringuelet

Roberto Jensen

Instituto de Limnologia Dr Raul a Ringuelet

Alberto Rodrigues Capítulo

Instituto de Limnologia Dr Raul a Ringuelet

\section{Research Article}

Keywords: invertebrates, aquatic plants, richness, functional feeding groups, wetlands, land use

Posted Date: November 1st, 2021

DOI: https://doi.org/10.21203/rs.3.rs-965908/v1

License: (c) (i) This work is licensed under a Creative Commons Attribution 4.0 International License.

Read Full License 


\section{Abstract}

The aim of this study was to investigate the effects of agricultural land use and periods of hydrological variability on the environmental variables, as well as macrophyte and macroinvertebrate assemblages in lowland riverine wetlands. We compared two wetlands with intensive agricultural land use against two others with extensive livestock considered references for the region during a normal and a dry flow period. Nutrient concentrations were significantly higher in agricultural riverine wetlands. These wetlands exhibited higher relative coverage of floating anchored macrophytes and the absence of submerged vegetation. They showed significantly lower taxonomic richness and density of macroinvertebrates and a higher relative abundance of scrapers and predators. Wetlands of both land uses had a lower total density of macroinvertebrates and a higher proportion of tolerant desiccation taxa in the dry period. Particular differences between land uses, such as lower dissolved oxygen concentrations and lower macroinvertebrate diversity in agricultural wetlands, were found during the dry period. These findings indicate that the differences between land uses increased during the aforementioned period. This study provides evidence of the effects of the surrounding landscape and hydrologic periods in the environmental characteristics as well as the macrophyte and macroinvertebrate assemblages of the riverine wetlands studied.

\section{Introduction}

Wetlands are globally recognized as essential due to the many ecological functions and services that they provide to human society (Dixon and Wood 2007). They provide water quality protection (Verhoeven et al. 2006; Daneshvar et al. 2017), climate change mitigation, flood control, and drought prevention (Mitsch and Gosselink 2000; Zedler and Kercher, 2005). They are also an important reservoir of flora and fauna (Sileshi et al. 2020; Gupta et al. 2020). Around the world, the wetlands are subjected to several types of threats, both anthropogenic and natural. Agriculture is currently considered the main driver of wetland loss or degradation globally (Davidson 2014; Everard and Wood 2017).

The replacement of natural ecosystems by agricultural land use produces a homogenization that threatens biodiversity (Allan 2004; Dornelas et al. 2009). The fertilizers applied indiscriminately in intensive agriculture activities are one of the most important sources of contamination by nutrient loading in freshwater ecosystems (Grashof-Bokdam and van Langevelde 2005; Strokal et al. 2016). The excess of these nutrients, such as phosphorus and nitrogen, transported to watercourses reduce water quality due to the increased growth of undesirable algae and low oxygen concentrations (Blann et al. 2009; Woodward et al. 2012). This has several negative effects on freshwater ecosystem biodiversity, like replacement and loss of species in their assemblages (Gustafson and Wang 2002; Craft et al. 2007; Chalar et al. 2013; Lange et al. 2014; Laterra et al. 2018). Furthermore, drainage and water management for agriculture has significantly altered the hydrology of wetlands affecting also its biodiversity (Blann et al. 2009; Lacoul and Freedman 2006; Green et al. 2017). Water withdrawals for agriculture have been found to markedly reduce streamflow, causing a loss of connection between the surface and the 
groundwater systems (Postel 2000) and resulting in a loss of habitat for aquatic biota (McKay and King 2006).

Riverine wetlands (RWs) are recognized as a major component of biodiversity in fluvial ecosystems (Amoros et al. 2000; Tockner et al. 2002). They are areas where streams overflow and connect with the surrounding terrestrial environment (Ringuelet, 1962; Brinson et al. 2002) and where macrophyte assemblages are highly developed (Amoros et al. 2000). As it is known, macrophytes are key components of wetlands ecosystems (Rejmánková 2011). They remove a variety of pollutants from the water (Bonanno and Vymazal 2017), and increase the habitat complexity and heterogeneity of these ecosystems (Thomaz and Cunha 2010). Also, they provide several resources for other organisms, like microhabitats (Dudley, 1988; Warfe et al. 2008), shelter (Heck and Crowder, 1991; Thomaz and Cunha 2010) and food (Dvořák, 1996; Díaz-Valenzuela et al. 2016).

Within the wetlands biota, macroinvertebrates play an important role in the overall functioning of these ecosystems as they occupy a central position in the food web and in organic matter cycling and energy flow (Batzer et al. 1999). The reduction in water quality caused by agricultural land use also leads to decreases in macroinvertebrate richness and density, as well as the decrease in the abundance of sensitive groups (Genito et al. 2002; Lange et al. 2014; Malacarne et al. 2016). In these sense, the macroinvertebrate assemblage is widely used as indicator of in-stream biotic integrity of the land use (Bunn et al. 2010), and the comprehensive analysis of their composition can provide an overview of wetland environmental status (Balcombe et al. 2005; Mereta et al. 2013).

The knowledge of biodiversity of RWs and the effects of land use and hydrological periods is necessary for ecosystem management and conservation plans. Our goal was to investigate the effects of intensive agricultural land use on the environmental variables and the macrophyte and macroinvertebrate assemblages of Pampean lowland RWs of Argentina, in time periods characterized by different hydrological conditions. We hypothesized that i) intensive agricultural land use induces changes in physical and chemical variables and in the structural and functional responses of macrophyte and macroinvertebrate assemblages; ii) an extraordinary dry period leads to variations in the assemblages and increases differences between land uses.

\section{Materials And Methods}

\section{Study area}

The study was conducted in the Pampean ecoregion of Buenos Aires, Argentina (Fig. 1). This region is a vast grassy plain that covers central Argentina. It has a humid and temperate climate, mean annual precipitation between 1000 and $1200 \mathrm{~mm}$, and a mean annual temperature of $16^{\circ} \mathrm{C}$ (Hurtado et al. 2006). Riverine wetlands of this region are threaten by agriculture that affects the water quality and alters the natural habitat (Gómez et al. 2016). In particular, RWs located in the Pampean plain of Argentina represent the low depressions of Pampean stream basins, characterized by abundant and diverse aquatic 
vegetation. The streams mentioned are characterized by an absence of riparian forest, low current velocities, and high nutrient levels (Rodrigues Capítulo et al. 2001; Feijoó and Lombardo 2007).

We selected two periurban RWs with intensive agricultural land use and other two with extensive livestock located on tributary streams of the freshwater section of the Río de la Plata estuary (Fig. 1, Online Resource: Table S1). The selection of this RWs was based on geohydrological and land use analysis (Rodrigues Capítulo et al. 2020; Gómez et al, in press). The four of them are located in characteristic Pampean streams and despite of their land use preserve their wetlands. Del Gato and the Carnaval RWs are in the agricultural area surrounding La Plata, the capital of the Province of Buenos Aires. This area is one of the main horticultural regions in the country (Baldini et al. 2019) with a high productivity based on intensive use of fertilizers and pesticides along with greenhouse technology (Arias et al. 2020).

Downstream, the Carnaval and Del Gato streams run through densely populated areas and their channels have been heavily impacted by anthropic action. The over-extraction for crop irrigation and drinking water supply of the city of La Plata and its surroundings has caused the local deepening of the water tables (Gómez et al. in press). This has contributed to the loss of groundwater supply to the base flow of the streams where these RWs occur (Deluchi et al. 2005; García and Zanandrea 2017). The other RWs, Cajaravillas and Chubichaminí, are located in Magdalena, a rural area with extensive livestock grazing on natural grassland ( 0.7 cows per ha., Gómez et al. in press). Freshwater systems surrounded by these grasslands are considered the reference for the region (Solis et al.; 2018; Arias et al. 2020; Paracampo et al. 2020). These RWs receive groundwater and surface water, with a greater volume being supplied by the former. Both RWs flow downstream through rural areas that do not hinder their natural drainage to the Río de la Plata estuary.

To know the effects of hydrological variation, four samplings were performed on the RWs. Two samplings were carried out during a period of normal flow, which we call "normal period" (September and October, mean monthly cumulative precipitation of $80 \mathrm{~mm}$ and $61 \mathrm{~mm}$ respectively), and two samplings in a dry period (February and early March). The monthly accumulative precipitations of this period were 2 $\mathrm{mm}$ in February and $92 \mathrm{~mm}$ in March, with $82 \mathrm{~mm}$ accumulated in the five days after the sampling date. The average precipitation recorded was lower than the historical mean monthly accumulated precipitation for the last ten years (National Meteorological Service: February $177 \mathrm{~mm}$ and March 123 $\mathrm{mm}$ ). This intense drought coincides with the "La Niña" phase of the ENSO phenomenon (Gómez et al. in press).

In each RW we selected a section of $50 \mathrm{~m}$ in the center of the channel, depending on the ease of access, where the sampling was carried out. In that section, in each sampling occasion, physical and chemical variables and macrophyte assemblage descriptors were measured and macroinvertebrates were sampled (see below). During the dry period, the RWs studied were characterized by lower width, lower water velocity, and lower flow in the four wetlands studied (Online Resource: Table S1). The Carnaval, one of the agricultural RWs, was completely dry during the February campaign.

\section{Site characterization}


The $\mathrm{pH}$, temperature, dissolved oxygen concentration (DO), conductivity, and total dissolved solids were measured in situ in triplicate with a HORIBA Multiparameter U-10. Besides, on each sampling occasion, a

water sample was collected for the analysis of nutrient concentrations (Total Nitrogen, Nitrates $\left[\mathrm{N}-\mathrm{NO}_{3}\right]$, Nitrites [N-NO $\mathrm{N}_{2}$, Ammonia [N-NH 4 , Total Phosphorus and Phosphate [P-PO (biochemical and chemical, BOD and COD, respectively) under standardized protocols (APHA, 1998).

\section{Macrophytes}

The macrophytes species, along with their coverage and life forms, were recorded. Five evenly-spaced transects were performed perpendicular to the channel in the section of $50 \mathrm{~m}$ in each wetland to calculate the macrophyte coverage. On each transect, the total coverage of each patch and species were estimated by measuring the length of the transect covered by the water and by each species (Feijoó and Menéndez 2009). In addition, total macrophyte coverage was calculated as the sum of total coverage values of present species. For this study, we classified the species as emergent, submerged, floating-leaved anchored, and free-floating (Cabrera, 1948; Lahitte et al. 2004).

\section{Macroinvertebrates}

Triplicate samples of the macroinvertebrates were taken from the present vegetation with a sieve of 500um mesh in a Plexiglas square $\left(625 \mathrm{~cm}^{2}\right.$ ) (Cortelezzi et al. 2013). The material was fixed in situ with $5 \%$ $(\mathrm{v} / \mathrm{v})$ aqueous formaldehyde. In the laboratory, the invertebrates were separated under a stereomicroscope, counted, and identified to the lowest possible taxonomic level through standard keys (Lopretto and Tell, 1995; Merritt et al. 2008; Domínguez and Fernández 2009).

\section{Data analysis and statistical approach}

The RWs along the physical and chemical variables were characterized by principal-component analysis (PCA). Before the analysis, the variables were standardized. The variables that presented little contribution, those that present low correlation with the first and the second component, were removed to simplify analysis (Kassambara 2017). Differences in physical and chemical variables between land uses and hydrological periods and their interaction were assessed by two-way ANOVA with 'RW' nested within 'land use'. The variables that did not fit with a normal distribution (temperature, conductivity, DO, Total Nitrogen and Total Phosphorus) were log-transformed. Pairwise comparisons on the main fixed factors were performed using Tukey's post hoc tests. Model residuals were tested for normality using a ShapiroWilk test.

The total coverage of macrophytes and the relative coverage of each life form expressed as percentages were calculated to characterize the macrophyte assemblage. Also, the richness was estimated as the number of taxa present, and diversity was estimated by the Shannon-Wiener Index (Shannon and Weaver, 1949). In addition, to characterize the macroinvertebrate assemblage, density was expressed as the average number of individuals per square meter, and richness and diversity were estimated. We assigned each taxon to a functional feeding group (FFG) using available references (Cummins et al. 
2005; Allan and Castillo 2007; Merritt et al. 2008). The relative abundance values of each FFG were calculated for each site and sampling occasion using macroinvertebrate densities (ind. $m \mathbb{\Xi}^{2}$ ).

Macrophyte coverage, diversity of both assemblages, as well as density and FFG of macroinvertebrates, were compared between land uses and hydrological periods by two-way ANOVA with 'RW' nested within 'land use'. The interaction between 'land use' and 'hydrological period' was also assessed. Density of macroinvertebrates data were log-transformed, whereas coverage of macrophytes and FFGs of macroinvertebrates were arcsine transformed to fit with the normal distribution. Pairwise comparisons on the main fixed factors were performed using Tukey's post hoc tests. Model residuals were tested for normality using a Shapiro-Wilk test. For count data (richness), we used generalized linear models (GLMs) with Poisson error distribution (link: log) for the same factors.

A Permutational Multivariate Analysis of Variance (PERMANOVA) was used to test differences in macroinvertebrate taxonomic composition between 'land use' (agriculture and livestock) and 'hydrological period' (normal and dry), with 'RWs' nested within 'land use'. The PERMANOVA was applied on a Bray-Curtis dissimilarity matrix calculated from the abundance data of macroinvertebrates. We also used a similarity percentage analysis (SIMPER) to identify taxa separating different land use categories and hydrological periods and to quantify the contribution of individual taxa to each category.

All statistical analysis were performed using the language environment $R$ version 3.6.3 ( $R$ Development Core Team 2020) and the RStudio Team (2015). The packages used for the analysis were FactoMineR (Lê et al. 2008), vegan (Oksanen et al. 2013), biodiversityR (Kindt and Coe 2005), and stats (R Development Core Team 2020).

\section{Results}

\section{Sites characterization}

The first two PCA axes explained $64.1 \%$ of the overall variance (Fig. 2). The first axis (43.5\%) illustrated the environmental differences between land uses. Agricultural RWs were characterized by higher nutrient concentration (total phosphorus, total nitrogen, soluble reactive phosphorus, and to a lesser extent, ammonium). By contrast, livestock RWs were characterized by higher values of $\mathrm{pH}$, conductivity, and TDS and lower values of nutrient concentrations (Online Resource: Table S2, correlations between axis and variables). The second axis ( $20.6 \%$ of the total variance) was positively correlated with temperature, nitrate, and nitrite whereas was negatively correlated with flow and dissolved oxygen. This axis showed the difference between hydrological periods in livestock RWs, with respect to temperature, DO and flow. The dry period was characterized by higher temperature, lower flow and DO in comparison with the normal period.

Significant differences were found in water physical and chemical characteristics between land uses (Table 1). Agricultural RWs exhibited higher values of total phosphorus $\left(F_{1,6}=34.50, p=0.001\right)$, total nitrogen $\left(F_{1,6}=116.94, p<0.001\right)$, and $\mathrm{P}^{-P O_{4}}\left(F_{1,6}=44.84, p<0.001\right)$. By contrast, livestock RWs had 
higher values of conductivity $\left(F_{1,34}=250.33, p<0.001\right)$, $\operatorname{TDS}\left(F_{1,34}=147.72, p<0.001\right)$ and $p H\left(F_{1,34}=\right.$ $169.51, p<0.001)$ in both hydrological periods. Dissolved oxygen concentration was lower in the dry period in comparison with normal period in RWs of both land uses and also, was lower in agricultural $R W s$ than in livestock RWs in the dry period $\left(F_{1,34}=4.480, p=0.042\right)$. In contrast, temperature was higher in the dry period in both land uses $\left(F_{1,34}=51.67, p<0.001\right)$. Biochemical oxygen demand showed differences between hydrological periods, with higher values in the dry period, only in agricultural RWs $\left(F_{1,6}=16.98, p=0.006\right)$.

\section{Macrophytes}

We recorded 15 species during the study, and the total coverage of macrophytes was always greater than $60 \%$ in the RWs studied (Table 2). No significant differences were found in richness (estimate $=0.18$, zvalue $=0.43, p=0.670$; estimate $=0.29$, zvalue $=0.65, p=0.51)$, diversity $\left(F_{1,7}=0.10, p=0.763 ; F_{1,7}=\right.$ $1.72, p=0.231)$ or total coverage $\left(F_{1,7}=0.00, p=0.956 ; F_{1,7}=0.94, p=0.346\right)$ between land uses and hydrological periods, respectively. Coverage of floating-anchored species was higher in agricultural RWs than in livestock RWs $\left(F_{1,7}=637.14, p<0.001\right)$, where coverage of emergent macrophytes was higher $\left(F_{1,7}=82.41, p<0.001\right)$. Submerged macrophytes were not recorded in agricultural RWs. Typha latifolia, H. ranunculoides, A. philoxeroides, and L. peploides were the dominant species in the agricultural RWs, whereas I. pseudacorus and S. californicus were the dominant in livestock RWs. Unlike the normal period characterized by a higher coverage of emergent macrophytes $\left(F_{1,7}=19.70, p=0.003\right)$, the dry period was characterized by a higher coverage of a free-floating species ( $L$. gibba, $\left.F_{1,7}=10.73, p=0.014\right)$. With respect to floating-anchored macrophytes they respond differently in each land use, decreasing their coverage in the dry period in agricultural RWs and increasing in that period in livestock ones (Online Resource: Table S3).

\section{Macroinvertebrates}

A total of 63 taxa of macroinvertebrates were collected in the RWs studied (Online Resource: Table S4). Taxa richness differed significantly between land uses (estimate $=0.39$, zvalue $=2.68, p=0.007$ ), with an average of 13 taxa in agricultural RWs and an average of 20 taxa in livestock RWs (Fig. 3). Mean density also differed between land uses $\left(F_{1,37}=31.26, p<0.001\right)$, with agricultural RWs showing half the density of livestock RWs (Fig. 3). In addition, the density found during the dry period for the two land uses was half that recorded for the normal period $\left(F_{1,37}=34.40, p<0.001, F i g .3\right)$. Diversity only showed significant differences between land uses in the dry period $\left(F_{1,37}=5.48, p=0.025\right)$, with higher values in livestock RWs than in agricultural RW (Online Resource: Table S5).

Regarding FFGs, 26 taxa were identified as predators, 23 as collector-gatherers, 7 as scrapers, 5 as collector-filterers, and 2 as shredders (Online Resource: Table S4). Free-living aquatic nematodes were not included in the FFG analysis due to the controversies in the FFG classification (Moens et al. 2006; López van Oosterom et al. 2013). In the comparison between land uses, agricultural RWs showed higher relative 
abundance of predators $\left(F_{1,37}=5.87, p=0.020\right)$ and scrapers $\left(F_{1,37}=6.15, p=0.012\right.$, Fig. 4). By contrast, livestock RWs exhibited a higher relative abundance of collector-gatherers in both periods $\left(F_{1,37}=6.50, p\right.$ $=0.015$ ) and a higher relative abundance of collector-filterers in the dry period, coinciding with a reduction of this FFG in the agricultural RWs (significant interaction, $F_{1,37}=10.567, p=0.002$; Fig. 4). Differences between hydrological periods were also found: the dry period exhibited higher relative abundance of predators $\left(F_{1,37}=28.63, p<0.001\right)$ than the normal period, which had a significantly higher relative abundance of shredders $\left(F_{1,37}=26.39, p<0.001\right.$, Fig. 4$)$.

The assemblage compositions differed significantly between land uses (PERMANOVA: pseudo- $\mathrm{F}_{1,37}=$ $16.46, P=0.001$ ) and hydrological periods (PERMANOVA: pseudo- $F_{1,37}=12.39, P=0.001$ ). Based on SIMPER analysis results, the dissimilarity between land uses in the normal period was $48 \%$, whereas the dissimilarity increased to $67 \%$ in the dry period. The taxa that contributed the most to differences between agriculture and livestock were Hyalella curvispina (Shoemaker, 1942) (5.80\%), Oligochaeta (5.33\%), Uncancylus concentricus (dOrbigny, 1835$)(5.29 \%)$, Cyclopoida (5.18\%), Cladocera (4.97\%), Chironomidae (4.79\%), and Caenis sp. (4.64\%) (with higher abundance in livestock than agricultural RWs) and Dugesiidae (4.68\%) and Entomobrydae (3.47\%) with higher abundance in agricultural RWs. The differences between hydrological periods were attributed to the decreased abundance of $H$. curvispina (7.92\% in livestock, $7.48 \%$ in agriculture), Dugesiidae (5.29\% in livestock, $10.42 \%$ in agriculture), and Caenis sp. (4.88\% in livestock) in dry periods and the increased abundance of particular taxa such as Nematoda (4.00\% in livestock, $4.09 \%$ in agriculture), Cyclopoida (3.79\% in livestock, $5.73 \%$ in agriculture), and Ceratopogonidae (4.43\% in livestock).

\section{Discussion}

Our results suggest that agricultural land use had a strong influence on the physical and chemical parameters, macrophyte structure, and macroinvertebrate metrics of the Pampean lowland RWs studied. The physical and chemical characteristics found for agricultural RWs denote water quality degradation of these wetlands in comparison with livestock RWs according to the first studies of the region (Tarda et al. 2019; Cochero et al. 2020; Gómez et al. in press).

The high concentration of nutrients in RWs with agriculture in their catchment is typical of freshwater systems in agricultural areas because the high amount of fertilizer used in crops increases the concentration of nutrients in the surrounding freshwater systems (Carpenter and Bennett 2011; Egler et al. 2012; Mugni et al. 2013; Ruiz-Picos et al. 2016). In contrast, the higher conductivity, TDS, and pH found in livestock RWs agreed with the characterization performed by Molina et al. (2017) for aquatic environments associated with pastures, herbaceous, and shrub vegetation. In particular, in pasture catchments like those studied, cattle have free access to wetlands for watering, which can increase the total dissolved solids and conductivity due to the constant disturbance and resuspension of the substrate (Gary et al. 1983; Roche et al. 2013). Also, the higher conductivity of the livestock RWs could be produced by the groundwater contribution (Caruso 2002). 
In accordance with our results, changes in macrophyte species resulting from agricultural land use were also recorded for USA wetlands (Gustafson and Wang 2002). Submerged macrophyte were absent and floating macrophyte coverage increased in agricultural lands, as documented in the context of increased nutrient load (Rasmussen and Anderson 2005). Species composition could change in relation to agricultural land use as well. In our work, we found $T$. latifolia and $H$. ranunculoides as the dominant species in agricultural sites. Typha spp. are considered to increase their dominance in nutrient-enriched wetlands (Cooper et al. 2006; Craft et al. 2007; Rejmánková 2011). These species can benefit from agricultural nutrient pulses by taking up nutrients rapidly and funneling them into growing tissues (Zedler and Kercher 2004). Similarly, H. ranunculoides is known to increase its growth and biomass with increasing nutrient availability in laboratory conditions (Hussner and Lösch 2007). But, not only the surrounding land use can determine the macrophyte composition, also the physical attributes and the hydrologic disturbance affects the relative abundance of macrophyte species (Lacoul and Freedman 2006). The higher concentration of TDS and the shallow and wide characteristic of the livestock RWs allowed the development of a higher coverage of emergent macrophytes in agreement with previous studies (Feijoó et al. 1999; Egertson et al. 2004). Despite the land use, macrophyte coverage was high in the four RWs studied, giving these wetlands a high habitat complexity (Thomaz and Cunha 2010). Regarding hydrological conditions, the high coverage of L. gibba found in the dry period correlates with the increase in the coverage of floating macrophytes documented at low flows by other authors (Cao et al. 2018; Fraaije et al. 2018). Lower flow velocities lead to a predominance of more typically lentic plant communities, such as free-floating species (Fraaije et al. 2018).

Although the use of macroinvertebrates as indicators of agricultural wetland land use is still discussed (Batzer 2013; Gleason and Rooney 2017), we found that this assemblage respond to the effect of agriculture on the studied RWs, and can be considered good indicators of land use in this wetlands. In agreement with the results found in other types of wetlands around the world, lower richness and density were observed in wetlands with intensive agricultural land use. That is the case for example for some Meditarrean littoral wetlands (Ortega et al. 2004) and ponds (Della Bella and Mancini 2009), North American floodplain wetlands (Chipps et al. 2006) and Chinese wetlands (Wu et al. 2019) impacted by intensive agricultural activities. In line with our results for RWs, Arias et al. (2020) and Solis et al. (2017) also found that mean density was twice as high between streams of the Pampean region with extensive livestock and intensive agriculture in their surroundings.

The reduction in taxonomic richness is usually related to the loss of sensitive taxa in agricultural land use (Gerth and Giannico 2017). High percentages of agricultural land cover reduced the number of sensitive macroinvertebrate taxa and produced a macroinvertebrate community composition that reflected an altered habitat (Genito et al. 2002). In coincidence with Mugni et al. (2013) and Solis et al. $(2017,2018)$, who studied streams in the Pampean region, our results in RWs suggest that the deterioration in water quality generated by intensive agriculture could cause a decrease on the abundance of sensitive macroinvertebrate taxa such as H. curvispina and Caenis sp. Cooper et al. (2006) also found less abundance of a Hyallela species (Hyalella azteca) in wetlands adjacent to agricultural land. In addition, we found that tolerant taxa such as Dugesidae and Entomobrydae characterized agricultural RWs, in 
coincidence with the results of Solis et al. (2018). We also recorded the presence of some sensitive invertebrates (Rodrigues Capítulo et al. 2001) that were found only in livestock RWs such as Lestes, Rhionaeschna, and individuals of the Simuliidae family.

Feeding strategies of macroinvertebrates could also reflect the adaptation of species to stressors and form part of a unified measure across communities differing in taxonomic composition (Tomanova et al. 2006). The effect of agricultural land use was reflected in a greater relative abundance of scrapers and predators in RWs. The increase in the frequency of scraper feeding habits is expected to occur in nutrientenriched environments (Dolédec et al. 2006; Statzner and Bêche 2010). On the other hand, predator abundance was associated with the higher density of Dugesiidae and Helobdella sp., considered tolerant taxa by other authors (Rodrigues Capítulo et al. 2001; Solis et al. 2019). The lowest proportion of collector-filterers in agricultural RWs in the dry period was in accordance with Gebrehiwot et al. (2017), who found a decrease in this FFG at organic polluted sites of Ethiopian wetlands in a dry period. Also, the relative abundance of this FFG is considered to be a useful metric for characterizing the ecological condition of river-associated wetlands in Eastern Africa (Mereta et al. 2013).

The presence of different life forms of macrophytes can also drive the composition of invertebrate FFG by determining the availability and type of food resources (Cremona et al. 2008; de Souza Rezende et al. 2019). In this sense, submerged macrophytes are usually related to a greater abundance of collectorsgatherers (Cremona et al. 2008; Peiró et al. 2015; de Souza Rezende et al. 2019), because its architecture allow the retention of more detritus (Sand-Jensen, 1998). In our study, this life form was absent in agricultural RWs in concordance with the lower proportion of this FFG. On the other hand, the highest proportion of predators in agricultural RWs and in the dry period could be related to the higher coverage of floating-leaved macrophytes. This life form provides little habitat in the vertical dimension that promotes a higher exposure to visual predators compared to the other macrophyte life forms (Gosselain et al. 2005). In this sense, the land use and hydrological period effects observed in the macrophyte assemblages could also contribute to the differences in the proportion of FFGs.

Much of the current knowledge about the ecological response of macroinvertebrates to droughts is related to the effects of largely predictable seasonal droughts rather than supra-seasonal events (Lake 2003). Species inhabiting temporal ecosystems that suffer predictable droughts have different resistance mechanisms, including tolerance to the deterioration of water quality conditions and the presence of desiccation-resistant life history stages (Bogan et al. 2017). Also, present resilience mechanisms as dispersal to rewetted habitats from refugia (Boulton and Lake 2008). On the other hand, faunal recovery from supra-seasonal droughts varies from one case to another (Lake 2003). Generally, species are vulnerable to these events as they are not adapted and cannot escape the disturbance events in time (Boulton 2003). The unusual absence of precipitation, the high evapotranspiration in summer, and the loss of connection with the groundwater in agricultural areas (Rodrigues Capítulo et al. 2020) led the Carnaval RW to be dry in the February campaign. The lower oxygen concentration in RWs surrounded by agricultural land indicated a higher effect of the dry period on the water characteristics of these RWs. According to Robinson et al. (2004), reduced flow commonly leads to decreases in dissolved-oxygen 
content, which is critical to the survival of many aquatic species and can also affect their distribution and abundance. This condition was associated with the lower macroinvertebrate diversity, the wide difference in taxa richness, and the higher dissimilarity in macroinvertebrate composition found in agricultural RWs in comparison with livestock RWs during the dry period.

In line with our findings on the RWs studied, it is known that natural low flows cause decreases in invertebrate densities (Wood and Armitage 2004). Some authors suggested that this decrease occurs in response to changes in competition and predation because habitat area decreases and food quality and quantity are altered by flow reduction (Cowx et al. 1984; Wood et al. 2000). Furthermore, invertebrate community composition often changes in response to low or reduced flow in streams (Gore et al. 2001; Suren et al. 2003) and wetlands (Sim et al. 2013). The increase in the density of particular taxa associated with the dry period in macroinvertebrate assemblages was similar to that reported by other authors. Larned et al. (2007) also found Nematoda and Copepoda to be resistant to desiccation. Desiccation-resistant stages are well-known in copepods (Dahms, 1995), and aquatic nematodes are believed to survive extended dry periods in a state of anhydrobiosis (Drummond et al. 2015). Moreover, Ceratopogonidae larvae appear almost immediately when surface flows resume, suggesting that they use the hyporheic zone as a refuge from surface drying (Stanley et al. 1994; Stubbington 2012). Conversely, H. curvispina and Caenis sp. decrease their abundance in the dry period. There are no previous reports on changes in the abundances of these taxa under drought conditions. However, other related species have been studied. Ladle and Bass (1981) and Wood and Armitage (2004) recorded similar responses of Gammarus pulex (L.) to dry conditions. Regarding Caenis sp., the reduced flow and decreased water velocity were documented to be detrimental to other Ephemeroptera taxa (Calapez et al. 2017). With regards to FFGs, in agreement with our results, the effects of a flow reduction in streams and wetlands were associated with an increase in the prevalence of predators and a decrease in shredders (Bêche et al. 2006; Statzner and Bêche 2010; Gebrehiwot et al. 2017). Reduced velocities could favor invertebrate predators by removing velocity-mediated predation refugia (Dewson et al. 2007) and affect shredder abundance by modifying the quality of resources (Statzner and Bêche 2010).

The results showed a synergetic effects of nutrient loading and hydrological disturbances in the RWs studied. Similar results were mentioned by Green et al. (2017) for the Doñana wetlands in Spain, a more complex system of wetlands than the studied. As mention these authors, decisions from informed policy makers can promote ecosystem resilience to global threats through local measures. The correct management of agricultural activities in the land surrounding a river, as part of integrated watershed management, is of paramount importance to the conservation of associated wetland water quality (Wang 2001). Therefore, unsustainable agricultural practices could be replaced with environmentally-friendly, ecological agriculture to preserve wetland ecosystems (Zou et al. 2018).

\section{Conclusions}

The findings provide strong evidence of the importance that the surrounding landscape has in the environmental characteristics and macrophyte and macroinvertebrate assemblages of lowland RWs. We 
conclude that the effects of intensive agricultural land use on physico-chemical variables, mainly nutrient enrichment, contributed to the differences found in macrophyte life form coverage and macroinvertebrate assemblages. The differences between land uses were greater during a drought period, which indicates a higher sensitivity to different hydrological conditions in those wetlands surrounded by intensive agricultural systems in comparison with those surrounding by extensive livestock considered as reference for the region.

Despite the land use, the great macrophyte coverage in the RWs studied indicates the importance of these systems in the basin and the value of their conservation. However, the differences found in macroinvertebrate FFGs could also be influenced by the composition of macrophyte assemblage, indicating the role and importance of this assemblage in lowland RWs. In this sense, the combined use of macrophytes and macroinvertebrate assemblages were a powerful tool for describing and assessing the studied riverine wetlands. The metrics evaluated were useful for studying the land use of the catchment and the hydrological conditions. This study provides valuable information to future conservation and management projects and to the scarce knowledge of this type of wetlands.

\section{Declarations}

Funding: This study was supported by the Consejo Nacional de Investigaciones Científicas y Técnicas [PIP 2013-0570]; the Institutional Project [PI UE-22920160100049CO], the Universidad Nacional de La Plata Projects [UNLP -FCNyM: 2014 11/ N 0738: 2018 11/ N 0869]; and the Fondo Nacional de Ciencia y Tecnología [PICT 2014-1342].

Conflicts of interest/Competing interests (include appropriate disclosures): This research does not present conflict of interest and has not being considered for publication elsewhere

Ethics approval (include appropriate approvals or waivers): Not applicable

Consent to participate (include appropriate statements) and Consent for publication (include appropriate statements): All the authors have fully participated in this manuscript and accept responsibility for it.

Availability of data and material (data transparency): We affirm that the data supports the results. The datasets used and analysed during the current study are available in the supplementary material and from the corresponding author on reasonable request.

Code availability (software application or custom code): not applicable.

\section{References}

1. Allan JD (2004) Landscapes and riverscapes: the influence of land use on stream ecosystems. Annu Rev Ecol Evol Syst 35:257-284. https://doi.org/10.1146/annurev.ecolsys.35.120202.110122 
2. Allan JD, Castillo MM (2007) Stream ecology: structure and function of running waters, 2nd edn. Springer Science \& Business Media, Dordrecht

3. APHA (American Public Health Association) (1998) Standard Methods for the Examination of Water and Waste Water, 20th edn. APHA, Washington

4. Amoros C, Bornette G, Henry CP (2000) A vegetation-based method for ecological diagnosis of riverine wetlands. Environ Manag 25:211-227. https://doi.org/10.1007/s002679910017

5. Arias M, Scalise A, Solis M, Paracampo A, Indaco M, Fanelli S, Mugni H, Bonetto C (2020) Horticulture affects macroinvertebrate assemblages in adjacent streams (Buenos Aires, Argentina). Knowl Manag Aquat Ecosyst 421:5. https://doi.org/10.1051/kmae/2019048

6. Balcombe CK, Anderson JT, Fortney RH, Kordek WS (2005) Aquatic macroinvertebrate assemblages in mitigated and natural wetlands. Hydrobiologia 541:175-188. https://doi.org/10.1007/s10750004-5706-1

7. Baldini C, Marasas ME, Drozd AA (2019) Entre la expansión urbana y la producción de alimentos. Rev Fac Agron Univ Nac La Plata 118:031-031. https://doi.org/10.24215/16699513e031

8. Batzer DP, Rader RB, Wissinger SA (1999) Invertebrates in freshwater wetlands of North America: ecology and management. John Wiley and Sons, New York

9. Batzer DP (2013) The seemingly intractable ecological responses of invertebrates in North American Wetlands: A review. Wetlands 33:1-15. https://doi.org/10.1007/s13157-012-0360-2

10. Blann KL, Anderson JL, Sands GR, James LA, Vondracek B (2009) Effects of agricultural drainage on aquatic ecosystems: A Review. Crit Rev Environ Sci Technol 39:909-1001. http://dx.doi.org/10.1080/10643380801977966

11. Bêche LA, Mcelravy EP, Resh VH (2006) Long-term seasonal variation in the biological traits of benthic-macroinvertebrates in two Mediterranean-climate streams in California, USA. Freshw Biol 51:56-75. https://doi.org/10.1111/j.1365-2427.2005.01473.x

12. Bogan MT, Hwan JL, Cervantes-Yoshida K, Ponce J, Carlson SM (2017) Aquatic invertebrate communities exhibit both resistance and resilience to seasonal drying in an intermittent coastal stream. Hydrobiologia 799:123-133. https://doi.org/10.1007/s10750-017-3205-4

13. Bonanno G, Vymazal J (2017) Compartmentalization of potentially hazardous elements in macrophytes: insights into capacity and efficiency of accumulation. J Geochem Explor 181:22-30. https://doi.org/10.1016/j.gexplo.2017.06.018

14. Boulton AJ (2003) Parallels and contrasts in the effects of drought on stream macroinvertebrate assemblages. Freshw Biol 48:1173-1185. https://doi.org/10.1046/j.1365-2427.2003.01084.x

15. Boulton AJ, Lake PS (2008) Effects of drought on stream insects and its ecological consequences. In: Lancaster J, Briers RA (eds) Aquatic Insects: Challenges to Populations. CAB International, Wallingford, pp 81-102

16. Brinson MM, Malvárez Al (2002) Temperate freshwater wetlands: Types, status, and threats. Environ Conserv 29:115-133. https://doi.org/10.1017/S0376892902000085 
17. Bunn SE, Abal EG, Smith MJ, Choy SC, Fellows CS, Harch BD, Kennard MJ, Sheldon F (2010) Integration of science and monitoring of river ecosystem health to guide investments in catchment protection and rehabilitation. Freshw Biol 55:223-240. https://doi.org/10.1111/j.13652427.2009.02375.x

18. Cabrera Al, Fabris H (1948) Plantas acuáticas de la Provincia de Buenos Aires. Publicación técnica Dirección Agropecuaria, La Plata, Argentina

19. Calapez AR, Branco P, Santos JM, Ferreira T, Hein T, Brito AG, Feio MJ (2017) Macroinvertebrate short-term responses to flow variation and oxygen depletion: a mesocosm approach. Sci Total Environ 599:1202-1212. https://doi.org/10.1016/j.scitotenv.2017.05.056

20. Cao HX, Fourounjian P, Wang W (2018) The importance and potential of duckweeds as a model and crop plant for biomass-based applications and beyond. In: Hussain C (ed) Handbook of environmental materials management. Springer, Cham, pp 1-16. https://doi.org/10.1007/978-3-31958538-3_67-1

21. Carpenter SR, Bennett EM (2011) Reconsideration of the planetary boundary for phosphorus. Environ Res Lett 6:14009. https://doi.org/10.1088/1748-9326/6/1/014009

22. Caruso BS (2002) Temporal and spatial patterns of extreme low flows and effects on stream ecosystems in Otago, New Zealand. J Hydrol 257:115-133. https://doi.org/10.1016/S00221694(01)00546-7

23. Chalar G, Delbene L, González-Bergonzoni I, Arocena R (2013) Fish assemblage changes along a trophic gradient induced by agricultural activities (Santa Lucía, Uruguay). Ecol Indic 24:582-588. https://doi.org/10.1016/j.ecolinD2012.08.010

24. Chipps SR, Hubbard DE, Werlin KB, Haugerud NJ, Powell KA, Thompson J, Johnson T (2006) Association between wetland disturbance and biological attributes in floodplain wetlands. Wetlands 26:497-508. https://doi.org/10.1672/0277-5212(2006)26[497:ABWDAB]2.0.C0;2

25. Cochero J, Di Giorgi H, Donadelli J, Suárez J, Simonetti R, Finkler NR, Cunha DGF (2020) El rol de los bañados de desborde fluvial en la retención de nutrientes y su actividad metabólica. Biol Acuat 35:013-013. https://doi.org/10.24215/16684869e013

26. Cooper MJ, Uzarski DG, Burton TM, Rediske RR (2006) Macroinvertebrate community composition relative to chemical/physical variables, land use and cover, and vegetation types within a Lake Michigan drowned river mouth wetland. Aquat Ecosyst Heal Manag 9:463-479. https://doi.org/10.1080/14634980600892655

27. Cowx IG, Young WO, Hellawell JM (1984) The influence of drought on the fish and invertebrate populations of an upland stream in Wales. Freshw Biol 14:165-177. https://doi.org/10.1111/j.13652427.1984.tb00030.x

28. Cortelezzi A, Sierra MV, Gómez N, Marinelli C, Rodrigues Capítulo AR (2013) Macrophytes, epipelic biofilm, and invertebrates as biotic indicators of physical habitat degradation of lowland streams (Argentina). Environ Monit Assess 185:5801-5815. https://doi.org/10.1007/s10661-012-2985-2 
29. Craft C, Krull K, Graham S (2007) Ecological indicator of nutrient enrichment, freshwater wetlands, Midwestern United States (US). Ecol Indic 7:733-750. https://doi.org/10.1016/j.ecolinD2006.08.004

30. Cremona F, Planas D, Lucotte M (2008) Biomass and composition of macroinvertebrate communities associated with different types of macrophyte architectures and habitats in a large fluvial lake. Fundam Appl Limnol 171:119-130

31. Cummins KW, Merritt RW, Andrade PC (2005) The use of invertebrate functional groups to characterize ecosystem attributes in selected streams and rivers in south Brazil. Stud Neotrop Fauna Environ 40:69-89. https://doi.org/10.1080/01650520400025720

32. Dahms HU (1995) Dormancy in the Copepoda - an overview. Hydrobiologia 306:199-211. https://doi.org/10.1007/BF00017691

33. Daneshvar F, Nejadhashemi AP, Adhikari U et al (2017) Evaluating the significance of wetland restoration scenarios on phosphorus removal. J Environ Manage 192:184-196. https://doi.org/10.1016/j.jenvman.2017.01.059

34. Davidson NC (2014) How much wetland has the world lost? Long-term and recent trends in global wetland area. Mar Freshw Res 65:934-941. https://doi.org/10.1071/MF14173

35. de Souza Rezende R, Monção FS, Gonçalves Junior JF, dos Santos AM (2019) Macroinvertebrate associated with macrophyte beds in a Cerrado stream. Limnetica 38:639-652. https://doi.org/10.23818/limn.38.37

36. Della Bella V, Mancini L (2009) Freshwater diatom and macroinvertebrate diversity of coastal permanent ponds along a gradient of human impact in a Mediterranean eco-region. In: Oertli B, Céréghino R, Biggs J, Declerck S, Hull A, Miracle MR (eds) Pond Conservation in Europe. Developments in Hydrobiology. Springer, Dordrecht, pp 181-197. https://doi.org/10.1007/978-90481-9088-1_16

37. Dewson ZS, James ABW, Death RG (2007) A review of the consequences of decreased flow for instream habitat and macroinvertebrates. J North Am Benthol Soc 26:401-415

38. Díaz-Valenzuela J, Barva-Alvarez R, Merlo-Galiazzi A, Zambrano L (2016) Macrophytes and metaphyton as habitats for insects in temporary and permanent tropical aquatic ecosystems. Neotrop Biodivers 2:171-180. https://doi.org/10.1080/23766808.2016.1248709

39. Dixon AB, Wood AP (2003) Wetland cultivation and hydrological management in eastern Africa: Matching community and hydrological needs through sustainable wetland use. Nat Resour Forum 27:117-129. https://doi.org/10.1111/1477-8947.00047

40. Dolédec S, Phillips N, Scarsbrook M, Riley RH, Townsend CR (2006) Comparison of structural and functional approaches to determining landuse effects on grassland stream invertebrate communities. J North Am Benthol Soc 25:44-60. https://doi.org/10.1899/0887$3593 \% 282006 \% 2925 \% 5 B 44 \% 3 A C O S A F A \% 5 D 2.0 . C 0 \% 3 B 2$

41. Domínguez E, Fernández HR (2009) Macroinvertebrados bentónicos sudamericanos: sistemática y biología Fundación Miguel Lillo. Tucumán, Argentina 
42. Dornelas $M$, Moonen AC, Magurran AE, Bàrberi $P$ (2009) Species abundance distributions reveal environmental heterogeneity in modified landscapes. J Appl Ecol 46:666-672.

https://doi.org/10.1111/j.1365-2664.2009.01640.x

43. Drummond LR, Mcintosh AR, Larned ST (2015) Invertebrate community dynamics and insect emergence in response to pool drying in a temporary river. Freshw Biol 60:1596-1612. https://doi.org/10.1111/fwB12591

44. Dudley TL (1988) The roles of plant complexity and epiphyton in colonization of macrophytes by stream insects. Verh Int Ver Theor Angew Limnol 23:1153-1158.

https://doi.org/10.1080/03680770.1987.11899786

45. Dvořák J (1996) An example of relationships between macrophytes, macroinvertebrates and their food resources in a shallow eutrophic lake. Hydrobiologia 339:27-36.

https://doi.org/10.1007/BF00008910

46. Egertson CJ, Kopaska JA, Downing JA (2004) A century of change in macrophyte abundance and composition in response to agricultural eutrophication. Hydrobiologia 524:145-156. https://doi.org/10.1023/B:HYDR.0000036129.40386.ce

47. Egler M, Buss DF, Moreira JC, Baptista DF (2012) Influence of agricultural land-use and pesticides on benthic macroinvertebrate assemblages in an agricultural river basin in southeast Brazil. Braz J Biol 72:437-443. http://dx.doi.org/10.1590/S1519-69842012000300004

48. Everard M, Wood A (2017) Agricultural management and wetlands: an overview. In: Finlayson CM, Everard M, Irvine K, Mclnnes R, Middleton B, van Dam A, Davidson NC (eds) The Wetland book I: structure and function, management, and methods. Springer, Beijing, pp 1009-1019. https://doi.org/10.1007/978-90-481-9659-3_194

49. Feijoó CS, Giorgi A, García ME, Momo F (1999) Temporal and spatial variability in streams of a pampean basin. Hydrobiologia 394:41-52

50. Feijoó CS, Lombardo RJ (2007) Baseline water quality and macrophyte assemblages in Pampean streams: a regional approach. Water Res 41:1399-1410.

https://doi.org/10.1016/j.watres.2006.08.026

51. Feijoó C, Menéndez M (2009) La biota de los ríos: los macrófitas. In: Elosegi A, Sabater S (eds) Conceptos y Técnicas en Ecología Fluvial. Fundación BBVa, Bilbao, pp 243-251

52. Fierro P, Bertrán C, Tapia J et al (2017) Effects of local land-use on riparian vegetation, water quality, and the functional organization of macroinvertebrate assemblages. Sci Total Environ 609:724-734. https://doi.org/10.1016/j.scitotenv.2017.07.197

53. Fraaije RG, Poupin C, Verhoeven JT, Soons MB (2018) Functional responses of aquatic and riparian vegetation to hydrogeomorphic restoration of channelized lowland streams and their valleys. J Appl Ecol 56:1007-1018. https://doi.org/10.1111/1365-2664.13326

54. Gary HL, Johnson SR, Ponce SL (1983) Cattle grazing impact on surface water quality in a Colorado front range stream. J Soil Water Conserv 38:124-128 
55. Gebrehiwot M, Awoke A, Beyene A, Kifle D, Triest L (2017) Macroinvertebrate community structure and feeding interactions along a pollution gradient in Gilgel Gibe watershed, Ethiopia: Implications for biomonitoring. Limnologica 62:68-76. https://doi.org/10.1016/j.limno.2016.11.003

56. Genito D, Gburek WJ, Sharpley AN (2002) Response of stream macroinvertebrates to agricultural land cover in a small watershed. J Freshw Ecol 17:109-119. https://doi.org/10.1080/02705060.2002.9663874

57. Gerth WJ, Li J, Giannico GR (2017) Agricultural land use and macroinvertebrate assemblages in lowland temporary streams of the Willamette Valley, Oregon, USA. Agric Ecosyst Environ 236:154165. https://doi.org/10.1016/j.agee.2016.11.010

58. Gleason JE, Rooney RC (2017) Aquatic macroinvertebrates are poor indicators of agricultural activity in northern prairie pothole wetlands. Ecol Indic 81:333-339.

https://doi.org/10.1016/j.ecolinD2017.06.013

59. Gomez D, Molineri C (2019) Crop landscapes reduced taxonomic and functional richness but increased evenness of aquatic macroinvertebrates in subtropical rivers. Environ Monit Assess 191:702. https://doi.org/10.1007/s10661-019-7864-7

60. Gómez N, Rodriguez Capítulo A, Collautti D et al (2016) La puesta en valor de los servicios ecosistémicos que ofrecen los arroyos de llanura pampeana como una medida de mitigación de las inundaciones: el caso de arroyo del gato en el partido de la plata. In: Volpedo A, de Cabo L, Arreghini S, Fernández Cirelli A (eds) Ecología y manejo de ecosistemas acuáticos pampeanos. Buenos Aires, Argentina, pp 39-52

61. Gómez N, Siri A, Capítulo LR et al (2021) Effects of urban demand for food and water on physicochemicals and biotic structure of riverine wetlands in the Pampean plain. Ecohydrol. https://doi.org/10.1016/j.ecohyD2021.08.006

62. Gore JA, Layzer JB, Mead J (2001) Macroinvertebrate instream flow studies after 20 years: a role in stream management and restoration. Regul Rivers Res Manage 17:527-542. https://doi.org/10.1002/rrr.650

63. Gosselain V, Hudon C, Cattaneo A, Gagnon P, Planas D, Rochefort D (2005) Physical variables driving epiphytic algal biomass in a dense macrophyte bed of the St-Lawrence River (Quebec, Canada). Hydrobiologia 534:11-22. https://doi.org/10.1007/s10750-004-1318-z

64. Grashof-Bokdam CJ, van Langevelde F (2005) Green veining: landscape determinants of biodiversity in European agricultural landscapes. Landsc Ecol 20:417-439. https://doi.org/10.1007/s10980-0045646-1

65. Green AJ, Alcorlo P, Peeters ET et al (2017) Creating a safe operating space for wetlands in a changing climate. Front Ecol Environ 15:99-107. https://doi.org/10.1002/fee.1459

66. Gupta G, Khan J, Upadhyay AK, Singh NK (2020) Wetland as a sustainable reservoir of ecosystem services: prospects of threat and conservation. In: Upadhyay AK, Singh R, Singh DP (eds) Restoration of wetland ecosystem: A trajectory towards a sustainable environment. Springer, Singapore, pp 31 43. https://doi.org/10.1007/978-981-13-7665-8_3 
67. Gustafson S, Wang D (2002) Effects of agricultural runoff on vegetation composition of a priority conservation wetland, Vermont, USA. J Environ Qual 31:350-357.

https://doi.org/10.2134/jeq2002.3500

68. Heck KL, Crowder LB (1991) Habitat structure and predator-prey interactions in vegetated aquatic systems. In: Bell SS, McCoy ED, Mushinsky HR (eds) Habitat Structure. Population and Community Biology Series. Springer, Dordrecht, pp 281-299. https://doi.org/10.1007/978-94-011-3076-9_14

69. Hurtado MA, Giménez JE, Cabral MG (2006) Análisis ambiental del partido de La Plata aportes del ordenamiento territorial, 1 st edn. Consejo Federal de Inversiones, Buenos Aires

70. Hussner A, Lösch R (2007) Growth and photosynthesis of Hydrocotyle ranunculoides L. fil. in Central Europe. Flora: Morphol Distrib Funct Ecol Plants 202:653-660.

https://doi.org/10.1016/j.florA2007.05.006

71. Kassambara A (2017) Practical guide to principal component methods in R: PCA, M (CA), FAMD, MFA, HCPC, factoextra. STHDA Marsella

72. Kindt R, Coe R (2005) Tree diversity analysis. A manual and software for common statistical methods for ecological and biodiversity studies. World Agroforestry Centre (ICRAF), Nairobi, Kenya

73. Lacoul P, Freedman B (2006) Environmental influences on aquatic plants in freshwater ecosystems. Environ Rev 14:89-136. https://doi.org/10.1139/a06-001

74. Ladle M, Bass JA (1981) The ecology of a small chalk stream and its responses to drying during drought conditions. Fundam Appl Limnol 90:448-466

75. Lahitte HB, Hurrell JA, Mehltreter K et al (2004) Biota Rioplatense I. Plantas de la costa: Nativas y exóticas. LOLA, Buenos Aires

76. Lake PS (2003) Ecological effects of perturbation by drought in flowing waters. Freshw Biol 48:1161-1172. https://doi.org/10.1046/j.1365-2427.2003.01086.x

77. Lange K, Townsend CR, Matthaei CD (2014) Can biological traits of stream invertebrates help disentangle the effects of multiple stressors in an agricultural catchment? Freshw Biol 59:24312446. https://doi.org/10.1111/fwB12437

78. Larned ST, Datry T, Robinson CT (2007) Invertebrate and microbial responses to inundation in an ephemeral river reach in New Zealand: effects of preceding dry periods. Aquat Sci 69:554-567. https://doi.org/10.1007/s00027-007-0930-1

79. Laterra P, Booman GC, Picone L, Videla C, Orúe ME (2018) Indicators of nutrient removal efficiency for riverine wetlands in agricultural landscapes of Argentine Pampas. J Environ Manage 222:148154. https://doi.org/10.1016/j.jenvman.2018.05.070

80. Lê S, Josse J, Husson F (2008) FactoMineR: an R package for multivariate analysis. J Stat Softw 25:1-18

81. López van Oosterom MV, Ocón CS, Brancolini F, Maroñas ME, Sendra ED, Rodrigues Capítulo A (2013) Trophic relationships between macroinvertebrates and fish in a pampean lowland stream (Argentina). Iheringia Ser Zool 103:57-65. https://doi.org/10.1590/S0073-47212013000100009 
82. Lopretto EC, Tell G (1995) Ecosistemas de aguas continentales. Ediciones Sur, La Plata, Argentina

83. Malacarne TJ, Baumgartner MT, Moretto Y, Gubiani ÉA (2016) Effects of land use on the composition and structure of aquatic invertebrate community and leaf breakdown process in Neotropical streams. River Res Appl 32:1958-1967. https://doi.org/10.1002/rrA3031

84. McKay SF, King AJ (2006) Potential ecological effects of water extraction in small, unregulated streams. River Res Appl 22:1023-1037. https://doi.org/10.1002/rrA958

85. Mereta ST, Boets P, De Meester L, Goethals PL (2013) Development of a multimetric index based on benthic macroinvertebrates for the assessment of natural wetlands in Southwest Ethiopia. Ecol Indic 29:510-521. https://doi.org/10.1016/j.ecolinD2013.01.026

86. Merrit RW, Cummins KW, Berg MB (2008) An Introduction to the Aquatic Insects of North America, 4th edn. Kendall/Hunt Publishing Company, Dubuque

87. Mitsch WJ, Gosselink JG (2000) The value of wetlands: importance of scale and landscape setting. Ecol Econ 35:25-33. https://doi.org/10.1016/S0921-8009(00)00165-8

88. Moens T, Traunspurger W, Bergtold M (2006) Feeding ecology of free-living benthic nematodes. Freshwater Nematodes. Ecology and Taxonomy. CAB International Publishing, pp 105-131

89. Molina MC, Roa-Fuentes CA, Zeni JO, Casatti L (2017) The effects of land use at different spatial scales on instream features in agricultural streams. Limnologica 65:14-21. https://doi.org/10.1016/j.limno.2017.06.001

90. Mugni H, Paracampo A, Bonetto C (2013) Nutrient concentrations in a pampasic first order stream with different land uses in the surrounding plots (Buenos Aires, Argentina). Bull Environ Contam Toxicol 91:391-395. https://doi.org/10.1007/s00128-013-1079-3

91. Oksanen J, Blanchet FG, Kindt R et al (2013) Package 'vegan'. Community ecology package version 2:1-295

92. Ortega M, Velasco J, Millán A, Guerrero C (2004) An ecological integrity index for littoral wetlands in agricultural catchments of semiarid mediterranean regions. Environ Manag 33:412-430

93. Paracampo A, Marrochi N, García I et al (2020) Fish Assemblages in Pampean Streams (Buenos Aires, Argentina): Relationship to Abiotic and Anthropic Variables. Anais Acad Brasil Ci 92:e20190476. https://doi.org/10.1590/0001-3765202020190476

94. Peiró DF, do Amaral GF, Saulino HHL (2015) Structure community of aquatic insects associated with different macrophytes in ornamental lakes in a Savanna region, Southeastern Brazil. Pan-Am J Aquat Sci 10:273-282

95. Postel SL (2000) Entering an era of water scarcity: the challenges ahead. Ecol Appl 10:941-948. https://doi.org/10.1890/1051-0761(2000)010[0941:EAEOWS]2.0.CO;2

96. R Development Core Team (2020) R: A language and environment for statistical computing. R Foundation for Statistical Computing, Vienna

97. RStudio Team (2015) RStudio: Integrated Development for R. RStudio, Inc., Boston 
98. Rasmussen P, Anderson NJ (2005) Natural and anthropogenic forcing of aquatic macrophyte development in a shallow Danish lake during the last 7000 years. J Biogeogr 32:1993-2005. https://doi.org/10.1111/j.1365-2699.2005.01352.x

99. Rejmánková E (2011) The role of macrophytes in wetland ecosystems. J Ecol Environ 34:333-345. https://doi.org/10.5141/JEFB2011.044

100. Ringuelet RA (1962) Ecología acuática continental. Manual de EUDEBA, Buenos Aires

101. Robinson CT, Uehlinger U, Monaghan MT (2004) Stream ecosystem response to multiple experimental floods from a reservoir. River Res Appl 20:359e377. https://doi.org/10.1002/rrA743

102. Roche LM, Kromschroeder L, Atwill ER, Dahlgren RA, Tate KW (2013) Water quality conditions associated with cattle grazing and recreation on national forest lands. PloS one 8:e68127. https://doi.org/10.1371/journal.pone.0068127

103. Rodrigues Capítulo A, Tangorraa M, Ocon C (2001) Use of benthic macroinvertebrates to assess the biological status of Pampean streams in Argentina. Aquat Ecol 35:109-119. https://doi.org/10.1023/A:1011456916792

104. Rodrigues Capítulo L, Kruse E, Gómez N (2020) Los bañados de desborde fluvial: una mirada desde la geohidrología. Biol Acuat 35:011-011. https://doi.org/10.24215/16684869e011

105. Ruiz-Picos RA, López-lópez JESE (2016) Ensambles de macroinvertebrados acuáticos relacionados con diversos usos del suelo en los ríos Apatlaco y Chalma-Tembembe (cuenca del Río Balsas), México. Hidrobiológica 26:443-458

106. Sand-Jensen K (1998) Influence of submerged macrophytes on sediment composition and near-bed flow in lowland streams. Freshw Biol 39:663-679. https://doi.org/10.1046/j.13652427.1998.00316.x

107. Shannon CE, Weaver W (1949) The mathematical theory of communication. University of Illinois Press, Urbana

108. Sileshi A, Awoke A, Beyene A, Stiers I, Triest L (2020) Water purifying capacity of natural riverine wetlands in relation to their ecological quality. Front Environ Sci 8:39. https://doi.org/10.3389/fenvs.2020.00039

109. Sim LL, Davis JA, Strehlow K, McGuire M, Trayler KM, Wild S, Papas PJ, O'Connor J (2013) The influence of changing hydroregime on the invertebrate communities of temporary seasonal wetlands. Freshw Sci 32:327-342. https://doi.org/10.1899/12-024.1

110. Solis M, Mugni H, Fanelli S, Bonetto C (2017) Effect of agrochemicals on macroinvertebrate assemblages in Pampasic streams, Buenos Aires, Argentina. Environ Earth Sci 76:180. https://doi.org/10.1007/s12665-017-6476-1

111. Solis M, Bonetto C, Marrochi N, Paracampo A, Mugni H (2018) Aquatic macroinvertebrate assemblages are affected by insecticide applications on the Argentine Pampas. Ecotoxicol Environ Saf 148:11-16. https://doi.org/10.1016/j.ecoenv.2017.10.017

112. Solis M, Arias M, Fanelli S, Bonetto C, Mugni H (2019) Agrochemicals' effects on functional feeding groups of macroinvertebrates in Pampas streams. Ecol Indic 101:373-379. 
https://doi.org/10.1016/j.ecolinD2019.01.036

113. Stanley EH, Buschman DL, Boulton AJ, Grimm NB, Fisher SG (1994) Invertebrate resistance and resilience to intermittency in a desert stream. Am Midl Nat 131:288-300. https://doi.org/10.2307/2426255

114. Statzner B, Bêche LA (2010) Can biological invertebrate traits resolve effects of multiple stressors on running water ecosystems? Freshw Biol 55:80-119. https://doi.org/10.1111/j.13652427.2009.02369.x

115. Strokal M, Ma L, Bai Z, Luan S, Kroeze C, Oenema O, Velthof G, Zhang F (2016) Alarming nutrient pollution of Chinese rivers as a result of agricultural transitions. Environ Res Lett 11:024014. https://doi.org/10.1088/1748-9326/11/2/024014

116. Stubbington $R$ (2012) The hyporheic zone as an invertebrate refuge: a review of variability in space, time, taxa and behaviour. Mar Freshw Res 63:293-311. https://doi.org/10.1071/MF11196

117. Suren AM, Biggs BJF, Duncan MJ, Bergey L, Lambert $P$ (2003) Benthic community dynamics during summer low-flows in two rivers of contrasting enrichment 2. Invertebrates. NZ J Mar Freshwater Res 37:71-83. https://doi.org/10.1080/00288330.2003.9517147

118. Tarda AS, Saparrat MCN, Gómez N (2019) Assemblage of dematiaceous and Ingoldian fungi associated with leaf litter of decomposing Typha latifolia L. (Typhaceae) in riverine wetlands of the Pampean plain (Argentina) exposed to different water quality. J Environ Manage 250:109409. https://doi.org/10.1016/j.jenvman.2019.109409

119. Thomaz SM, Cunha ER (2010) The role of macrophytes in habitat structuring in aquatic ecosystems: methods of measurement, causes and consequences on animal. Acta Limnol Bras 22:218-236. https://doi.org/10.4322/actalB02202011

120. Tockner K, Ward JV, Edwards PJ, Kollmann J (2002) Riverine landscapes: an introduction. Freshw Biol 47:497-500. https://doi.org/10.1046/j.1365-2427.2002.00913.x

121. Tomanova S, Goitia E, Helešic J (2006) Trophic levels and functional feeding groups of macroinvertebrates in neotropical streams. Hydrobiologia 556:251-264. https://doi.org/10.1007/s10750-005-1255-5

122. Verhoeven JT, Arheimer B, Yin C, Hefting MM (2006) Regional and global concerns over wetlands and water quality. Trends Ecol Evol 21:96-103. https://doi.org/10.1016/j.tree.2005.11.015

123. Wang $X$ (2001) Integrating water-quality management and land-use planning in a watershed context. J Environ Manage 61:25-36. https://doi.org/10.1006/jemA2000.0395

124. Warfe DM, Barmuta LA, Wotherspoon S (2008) Quantifying habitat structure: surface convolution and living space for species in complex environments. Oikos 117:1764-1773. https://doi.org/10.1111/j.1600-0706.2008.16836.x

125. Wood PJ, Agnew MD, Petts GE (2000) Flow variations and macroinvertebrate community responses in a small groundwater-dominated stream in south-east England Hydrol Process 14:3133-3147. https://doi.org/10.1002/1099-1085(200011/12)14:16/17<3133::AID-HYP138>3.0.CO;2-J 
126. Wood PJ, Armitage PD (2004) The response of the macroinvertebrate community to low-flow variability and supra-seasonal drought within a groundwater dominated stream. Fundam Appl Limnol 161:1-20. https://doi.org/10.1127/0003-9136/2004/0161-0001

127. Woodward G, Gessner MO, Giller PS et al (2012) Continental-scale effects of nutrient pollution on stream ecosystem functioning. Science 336:1438-1440. https://doi.org/10.1126/science.1219534

128. Wu H, Lu K, Lyu X, Xue Z (2019) A macroinvertebrate multimetric index for the bioassessment of wetlands adjacent to agriculture fields in the Sanjiang plain, China. Chin Geogr Sci 29:974-984. https://doi.org/10.1007/s11769-019-1083-6

129. Zedler JB, Kercher S (2004) Causes and Consequences of Invasive Plants inachiev Wetlands: Opportunities, Opportunists, and Outcomes. Crit Rev Plant Sci 23:431-452. https://doi.org/10.1080/07352680490514673

130. Zedler JB, Kercher S (2005) Wetland resources: status, trends, ecosystem services, and restorability. Annu Rev Environ Resour 30:39-74. https://doi.org/10.1146/annurev.energy.30.050504.144248

131. Zou Y, Wang L, Xue Z et al (2018) Impacts of Agricultural and Reclamation Practices on Wetlands in the Amur River Basin, Northeastern China. Wetlands 38:383-389. https://doi.org/10.1007/s13157017-0975-4

\section{Tables}

Table 1. Mean and standard error of physico-chemical variables in the riverine wetlands of agricultural and livestock land use in the two hydrological periods. Significantly higher values between land uses $(p<$ 0.05 ) are underlined, ${ }^{a}$ significant difference between hydrological periods, ${ }^{b}$ significant differences in the interaction. 


\begin{tabular}{|c|c|c|c|c|}
\hline & \multicolumn{2}{|l|}{ Agriculture } & \multicolumn{2}{|l|}{ Livestock } \\
\hline & normal & dry & normal & dry \\
\hline Temperature $\left(\mathrm{T}^{\circ},{ }^{\circ} \mathrm{C}\right)$ & $\begin{array}{l}18.78 \pm \\
0.23\end{array}$ & $\begin{array}{l}20.44 \pm \\
0.13^{a}\end{array}$ & $\begin{array}{l}17.61 \pm \\
0.35\end{array}$ & $\begin{array}{l}21.27 \pm \\
0.29^{\mathrm{a}}\end{array}$ \\
\hline $\mathrm{pH}$ & $7.18 \pm 0.07$ & $6.83 \pm 0.02$ & $\underline{8.16 \pm 0.04}$ & $\underline{8.2 \pm 0.01}$ \\
\hline Conductivity (Cond, ms/cm) & $0.35 \pm 0.02$ & $0.29 \pm 0.01$ & $\underline{0.74 \pm 0.01}$ & $1.02 \pm 0.03$ \\
\hline Dissolved oxygen (DO, mg/l) & $6.01 \pm 0.26$ & $2.75 \pm 0.03^{b}$ & $6.97 \pm 0.26$ & $4.6 \pm 0.31^{\mathrm{b}}$ \\
\hline Total dissolved solids (TDS, g/l) & $0.23 \pm 0.01$ & $0.19 \pm 0.01$ & $\underline{0.47 \pm 0.01}$ & $\underline{0.65 \pm 0.02}$ \\
\hline Nitrates $\left(\mathrm{N}-\mathrm{NO}_{3}, \mathrm{mg} \mathrm{N} / \mathrm{l}\right)$ & $0.05 \pm 0.01$ & $0.03 \pm 0$ & $0.03 \pm 0.01$ & $0.05 \pm 0.01$ \\
\hline Nitrites $\left(\mathrm{N}-\mathrm{NO}_{2}, \mathrm{mg} \mathrm{N} / \mathrm{l}\right)$ & $0.03 \pm 0.01$ & $0.03 \pm 0$ & $0.02 \pm 0$ & $0.04 \pm 0$ \\
\hline Ammonia $\left(\mathrm{N}-\mathrm{NH}_{4}, \mathrm{mg} \mathrm{N} / \mathrm{l}\right)$ & $0.12 \pm 0.02$ & $0.18 \pm 0.06$ & $0.11 \pm 0.03$ & $0.06 \pm 0.01$ \\
\hline Phosphate $\left(\mathrm{P}-\mathrm{PO}_{4}, \mathrm{mg} \mathrm{P} /\right.$ litro $)$ & $\underline{1.04 \pm 0.1}$ & $\underline{1.15 \pm 0.09}$ & $0.1 \pm 0.01$ & $0.26 \pm 0.03$ \\
\hline Total Phosphorus (Total P, mg P/l) & $\underline{1.54 \pm 0.21}$ & $\underline{1.48 \pm 0.19}$ & $0.5 \pm 0.09$ & $0.41 \pm 0.01$ \\
\hline Total Nitrogen (Total N, mg N/l) & $\underline{3.37 \pm 0.19}$ & $\underline{\underline{12.18 \pm}}$ & $2.92 \pm 0.18$ & $2.22 \pm 0.17$ \\
\hline $\begin{array}{l}\text { Biochemical oxygen demand (BOD, } \\
\mathrm{mgO}_{2} / \mathrm{l} \text { ) }\end{array}$ & $8.75 \pm 1.48$ & $28 \pm 1.5^{\mathrm{a}}$ & $\begin{array}{l}14.25 \pm \\
0.69\end{array}$ & $10.58 \pm 1.07$ \\
\hline Chemical oxygen demand (COD, $\left.\mathrm{mgO}_{2} / \mathrm{l}\right)$ & $47.5 \pm 2.58$ & $\begin{array}{l}81.33 \pm \\
9.72\end{array}$ & $75.5 \pm 2.2$ & $49.42 \pm 2.86$ \\
\hline
\end{tabular}

Table 2. Macrophyte species coverage ( $* 5 \%$; $* \star 5-25 \%$; $* \star \star>25 \%$ ) at the agricultural and livestock RWs in the two hydrological periods. Also, total coverage and life forms are given: E, Emergent; F-A, Floating anchored; F-F, Free-floating; S, Submerged. 
Agriculture Livestock

Species

Life normal dry normal dry forms

\begin{tabular}{|c|c|c|c|c|c|}
\hline Typha latifolia L. & E & ** & 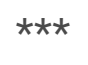 & * & \\
\hline Sagitaria montevidendis CHAM. et SCHLTDL. & $\mathrm{E}$ & * & * & & \\
\hline Eleocharis montana (H.B.K.) ROEM. Et Schult. & E & * & & ** & \\
\hline Polygonum punctatum Elliot & E & * & 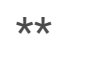 & * & \\
\hline Iris pseudacorus L. & E & & & *** & * \\
\hline Gymnocoronis spilanthoides (Don) DC. & E & * & & ** & ** \\
\hline Schoenoplectus californicus (C. A. Meyer) Soják & E & & & $\star * *$ & *** \\
\hline Lilaeopsis sp. Greene & $\mathrm{E}$ & * & & & \\
\hline Hydrocotyle ranunculoides $\mathrm{L}$. & F-L & 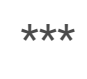 & * & * & $\star \star$ \\
\hline Althernantera philoxeroides (Mart.) Griseb. & F-L & $\star *$ & $\star *$ & & \\
\hline Ludwigia peploides (Kunth) P. H. Raven & F-L & $\star \star$ & ** & & * \\
\hline Lemna gibba L. & F-F & & ** & & ** \\
\hline Myriophyllum aquaticum (Vell.) Verdc. & $S$ & & & * & * \\
\hline $\begin{array}{l}\text { Stuckenia pectinata (L.) Börner [= Potamogeton } \\
\text { pectinatus (L.)] }\end{array}$ & $S$ & & & * & \\
\hline Ceratophyllum demersum L. & $S$ & & & & $\star \star$ \\
\hline Total coverage (\%) & & 67 & 87 & 85 & 84 \\
\hline
\end{tabular}

\section{Figures}




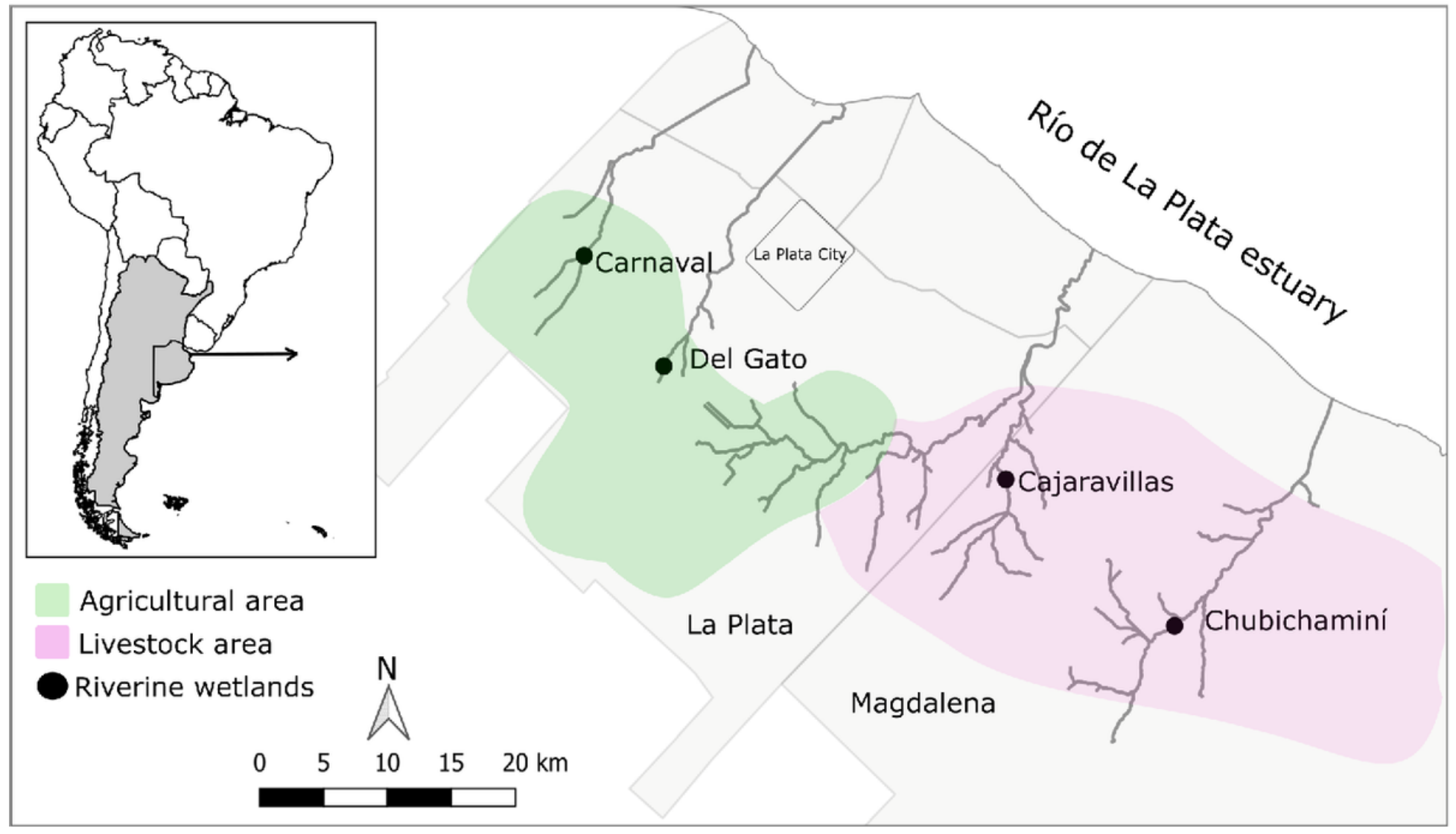

\section{Figure 1}

Map of the study area and the sampling sites located in Buenos Aires province, Argentina. Land use areas modified from Solis et al. (2019). 


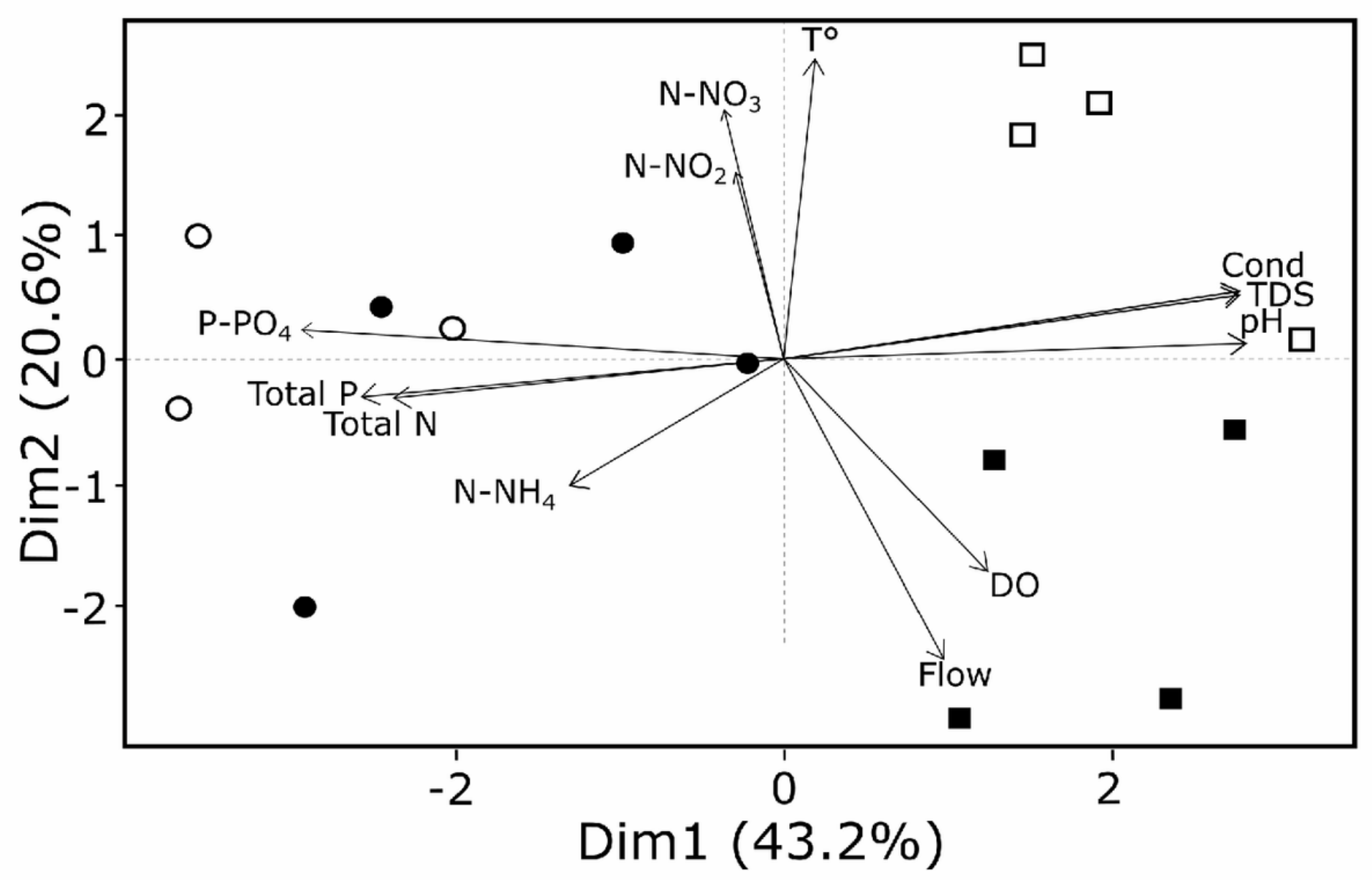

Figure 2

Principal Component Analysis of the analyzed physico-chemical variables in the four riverine wetland studied in the sampled period. Circles: agricultural land use; squares: livestock land use. Closed symbols: normal period; open symbols: dry period. See Table 1 for abbreviations.

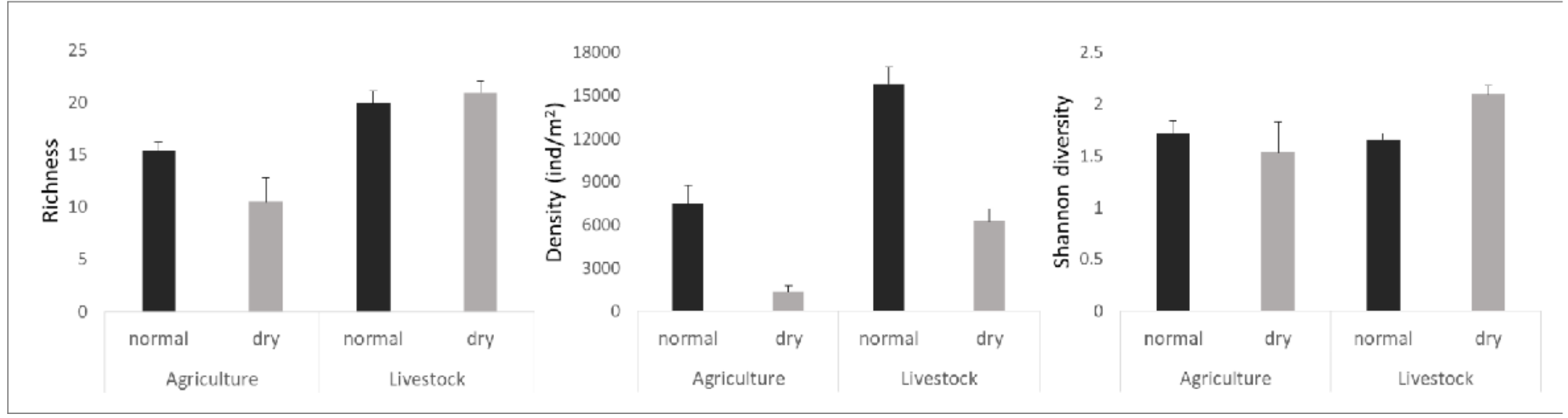

Figure 3

Mean and standard error of macroinvertebrate taxa richness, density and Shannon diversity in the agricultural and livestock RWs in the two hydrological periods. 


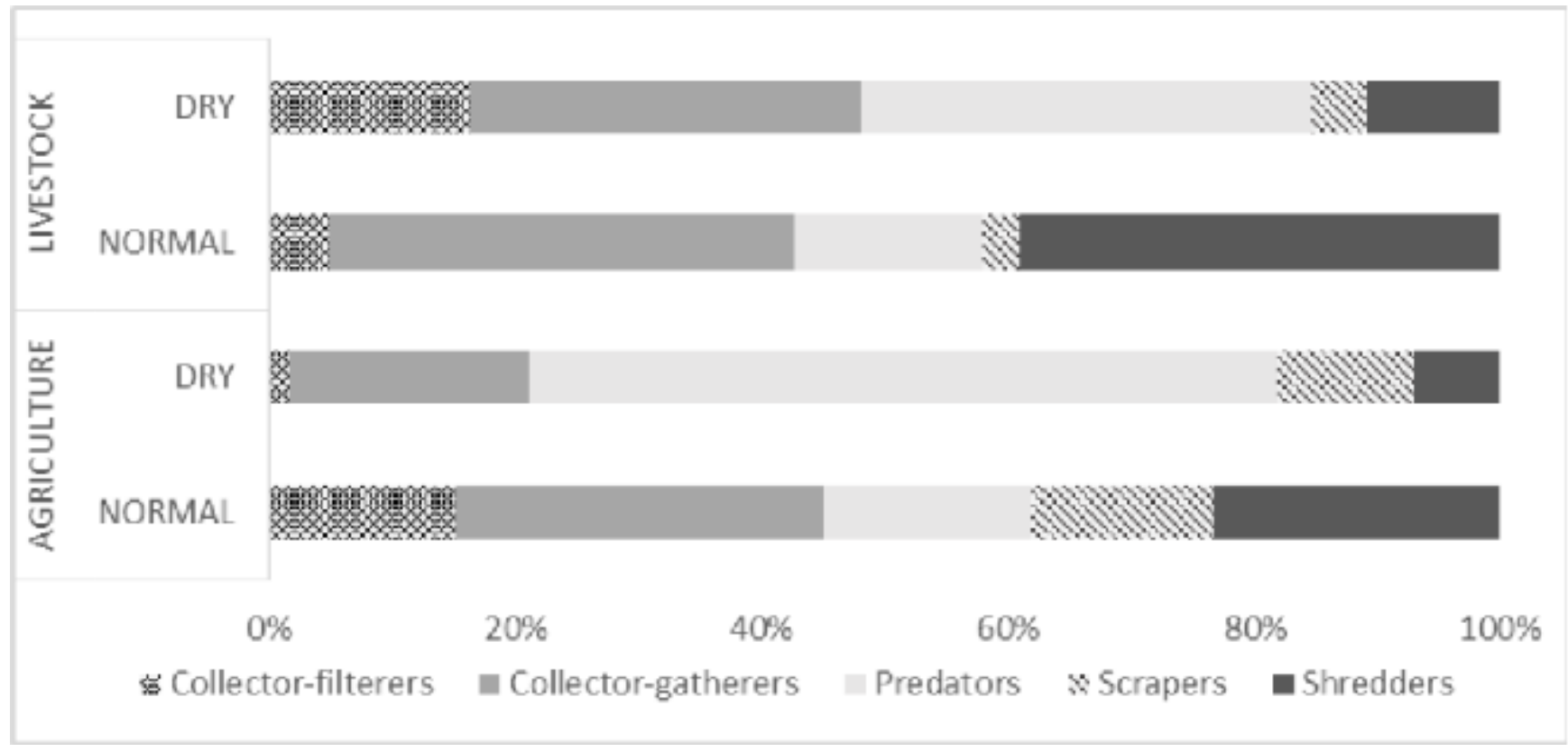

\section{Figure 4}

Relative abundance of macroinvertebrate functional feeding groups in the agricultural and livestock RWs in the two hydrological periods.

\section{Supplementary Files}

This is a list of supplementary files associated with this preprint. Click to download.

- ESM1.pdf 